Salivary levels of C-Reactive Protein (CRP), Procalcitonin (PCT) and Neutrophil Elastase (NE) were assessed in patients with COPD to determine if saliva could provide an alternative diagnostic bio-sample to blood. As the clinical usefulness of biomarkers relies on correlation to patient events, we also explored the relationship between target saliva analyte levels and wellbeing scores on breathing and activities of daily living (ADL), recorded in a purposeful diary.

The study included 139 subjects: 17 healthy non-smokers; 24 healthy smokers; 98 patients with COPD [Global Initiative for Chronic Obstructive Lung Disease (GOLD) Stage I, 16; Stage II, 32; Stage III, 39; Stage IV, 11]. Participants were assessed over 3 visits, one week apart and involving patient completion of a self-assessment diary, spirometry and, saliva sampling. 22 randomly selected COPD subjects provided simultaneous blood samples. Each salivary biomarker could distinguish across the 3 health status groups; however when adjusted for confounding factors this significance only remained for salivary NE, which was increased in healthy smokers compared to healthy nonsmokers $(\mathrm{p}<0.001)$ and stable COPD subjects $(\mathrm{p}<0.001)$. Patients with an acute exacerbation of COPD $(n=36)$ had a median increase in all 3 salivary biomarkers $(\mathrm{p}<0.001)$. CRP: median $5.74 \mathrm{ng} / \mathrm{ml}$, [interquartile range 2.86-12.25], (95\% Confidence Interval (CI): 3.72-11.47); PCT $0.38 \mathrm{ng} / \mathrm{ml}$, [0.220.94], (95\% CI: 0.31-0.54) and NE $539 \mathrm{ng} / \mathrm{ml}$ [112.25-1264], (95\% CI: 169-982). Salivary CRP and PCT concentrations strongly correlated with their serum counterparts; salivary NE did not. Salivary CRP and PCT levels correlated with breathing scores $(\mathrm{r}=0.14, \mathrm{p}<0.02 ; \mathrm{r}=0.13, \mathrm{p}<0.03$ respectively) but not with activities of daily living. Salivary NE showed no relationship to wellbeing scores.

Salivary CRP, PCT and NE provide clinically relevant information on disease status in COPD, and additionally NE on smoking status in healthy individuals. These results provide the conceptual basis for saliva to be used as a bio-sample in COPD monitoring.

\begin{tabular}{|c|c|c|c|}
\hline \multicolumn{4}{|c|}{ Matched COPD Subjects $(n=36)$} \\
\hline Demographic & Stable & Exacerbation & $P$ value \\
\hline $\mathrm{FEV}_{1}$, $\%$ predicted & $53 \pm 23$ & $48 \pm 19$ & $<0.001$ \\
\hline MRC Score & $5.00,1.25$ & $5.00,1.25$ & $<0.16$ \\
\hline Breathing Score & $3.00,0.00$ & $4.00,1.00$ & $<0.006$ \\
\hline ADL Score & $3.00,1.00$ & $4.00,2.00$ & $<0.014$ \\
\hline \multicolumn{4}{|l|}{ Sputum } \\
\hline Amount & $2.00,2.00$ & $3.00,2.25$ & $<0.001$ \\
\hline Texture & $1.94,0.33$ & $2.06,0.41$ & $<0.05$ \\
\hline Colour & $3.00,1.00$ & $4.00,1.50$ & $<0.001$ \\
\hline \multicolumn{4}{|l|}{ Salivary Biomarkers ${ }^{b}$} \\
\hline CRP, ng/ml & $1.61,1.10$ & $7.35,10.04$ & $<0.001$ \\
\hline $\mathrm{PCT}, \mathrm{ng} / \mathrm{ml}$ & $0.09,0.06$ & $0.50,0.71$ & $<0.001$ \\
\hline $\mathrm{NE}, \mathrm{ng} / \mathrm{ml}$ & 128,190 & 769,1680 & $<0.001$ \\
\hline \multicolumn{4}{|c|}{$\begin{array}{l}\text { a, Mean } \pm \text { standard deviation } \\
\text { b, Median, inter-quartile range } \\
\text { COPD = Chronic Obstructive Pulmonary Disease; FEV }{ }_{1}=\text { Forced Expiratory Volume in } 1 \text { sec- } \\
\text { ond; } M R C=\text { Medical Research Council; ADL = Activity of Daily Living; CRP = C-Reactive } \\
\text { Protein; PCT = Procalcitonin; NE = Neutrophil Elastase. } \\
\text { P values represent the difference between stable and exacerbation phase. }\end{array}$} \\
\hline
\end{tabular}

\section{P65 \\ STATIC BALANCE DEFICIT IN CHRONIC OBSTRUCTIVE PULMONARY DISEASE: PREVALENCE, CLINICAL CHARACTERISTICS AND RISK OF SIGNIFICANT FALLS}

JL Canavan, SSC Kon, CM Nolan, SE Jones, MI Polkey, Wd-C Man. NIHR Respiratory Biomedical Research Unit, Royal Brompton and Harefield NHS Foundation Trust and Imperial College, UK, Harefield, Middlesex, UK

\subsection{6/thoraxjnl-2014-206260.206}

Background Balance deficits are associated with increased risk of falls. The tandem stand (maintaining heel to toe stance for 10 seconds or more) is an established practical measure of static balance, and is associated with increased risk of falls and disability in community dwelling adults. The aim of the study was to establish the prevalence of static balance deficit in outpatients with stable COPD and any association with exercise capacity, lower limb muscle function and health related quality of life. Furthermore, it is not known whether the tandem stand predicts future risk of significant falls in patients with COPD.

Method 174 outpatients with stable COPD (mean (SD) age 70 (9) years, $\mathrm{FEV}_{1} 50(21) \%$ predicted) were stratified according to their ability to successfully complete the tandem stand. The incremental shuttle walk (ISW) test, habitual gait speed over 4 metres (4MGS), quadriceps maximal voluntary contraction (QMVC), the COPD assessment test (CAT), physical activity levels (defined as time spent in $>3$ METS according to the modified Minnesota Leisure-time Physical Activity Questionnaire) were also recorded. Self-reported falls and significant falls (defined as fall resulting in fracture or cerebral injury), corroborated by primary care records, were recorded over the following 12 months. Results 24\% could not complete the tandem stand. Compared to those able to complete a tandem stand, these patients were significantly older, had lower maximal exercise capacity, weaker quadriceps muscle force and reduced daily physical activity (Table 1). No significant falls were reported within the whole cohort, but 20 patients (11\%) reported non-injury falls after 12 months of follow-up (failed tandem: 19\% versus successful tandem: $9 \% ; \mathrm{p}=0.10$ )

Conclusion Static balance deficit is common in patients with COPD, and is associated with reduced exercise capacity, quadriceps weakness and reduced daily physical activity. The tandem stand does not predict future risk of falls. Significant falls were not observed in this cohort.

\begin{tabular}{|c|c|c|c|c|}
\hline & $\begin{array}{l}\text { Impaired } \\
\text { balance } \\
(n=42)\end{array}$ & $\begin{array}{l}\text { Completed } \\
\text { Tandem stand } \\
(\mathrm{n}=132)\end{array}$ & $\begin{array}{l}\text { Mean } \\
\text { difference } \\
(95 \% \mathrm{Cl})\end{array}$ & p-value \\
\hline Age (years) & $74(9)$ & $69(9)$ & 5.1 (2 to 8$)$ & 0.002 \\
\hline $\mathrm{FEV}_{1}$ (\% predicted) & $55(39,77)$ & $48(30,61)$ & $9(4)$ & 0.02 \\
\hline ISW (metres) & $166(109)$ & $252(127)$ & $-90(-130$ to -40$)$ & 0.0001 \\
\hline САТ & $20.3(7.7)$ & $20.4(7.4)$ & $-0.1(-2.7$ to 2.5$)$ & 0.95 \\
\hline Peak QMVC (kg) & $21.8(8.9)$ & $25.3(9.0)$ & $-4.7(-8.5$ to -0.9$)$ & 0.02 \\
\hline 4MGS (m/s) & $0.81(0.2)$ & $0.98(0.2)$ & 0.17 (0.1 to 0.04$)$ & $<0.0001$ \\
\hline \multicolumn{5}{|l|}{ Activity in $>3$ METS } \\
\hline (minutes) & $110(40,344)$ & $285(104,567)$ & $14(-272$ to 301$)$ & 0.92 \\
\hline \multicolumn{5}{|l|}{ Number reporting } \\
\hline falls in 12 months & 8 & 12 & - & 0.10 \\
\hline
\end{tabular}

